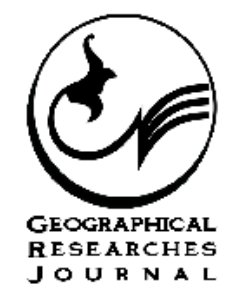

\title{
Evaluation of Erosion and Ssedimentation Areas of Drainage Basins of Makran Coastal Using Non-dimensional Hypsometric Curves
}

\section{ART ICLE INF 0}

\section{Article Type}

Original Research

\section{Authors}

Pourzare M. ${ }^{1} M A$,

Seif A.* $P h D$

\begin{abstract}
A B S T R A C T
Introduction and Background Geomorphic quantitative indices are useful for identifying specific features of a particular region, especially in tectonic studies. One of these indicators is the hypsometric curves (hypersometry) and the hypersonic integral which is used to indicate the potential of the regions in terms of tectonic activity in order to assess the areas under erosion and sedimentation of drainage areas.

Aims The aim of this study investigates the physical characteristics of the catchment areas of the Makran coastline in terms of their erosion characteristics and sedimentation using non-dimensional hypsometric curves.

Methodology In this study, for extraction of the network of streams and their ranking, a digital elevation model of the region with Resolution of 10 meters was ranked according to the Australian method. In the Python programming environment, it was coded to calculate the values of tables and plot the dimensionless hypersonic curves for analyzing the erosion state And sedimen-tation in the entire surface of the watershed of Makran coastal areas as well as drainage basins.

Conclusion Measuring the Hypsometric Curve Index shows that they are balanced in the main basin of geomorphologic processes. Considering the values of the table and drawing of the hypsometric curve of the whole area of the region, it shows a balanced expansion of plain and altitude. But calculating the hypsometric curve and integral in the sub-basins of the study area shows that the northern part of the sub-basins, tectonic processes are superior to erosion processes. If in the southern sub-basins, erosion processes take precedence over tectonic processes or geomorphologic processes act in a bal-anced manner. With the influence of geological parameters and the creation of tectonic anomalies, the land will be changed and erosion in the basins will be changed. The total thickness of the drainage basin is $20 \%$. Keywords PNEO-TECTONICS; Non-Dimensional and Integral Hyssometric Curves; Drainage Basins of Makran Coastal; Erosion
\end{abstract}

\section{CITATION L INKS}

[Abedini \& Shabrang; 2014] Evaluation of neo tectonic activities in Meshkin Chai Catchment ...; [Chen, et al.; 2003] Along-strike variations of morphotectonic features in ...; [Dehbozorgi et al.; 2010] Quantitative analysis of relative tectonic activity in the ...; [El Hamdouni, et al.; 2008] Assessment of relative active tectonics, southwest border ...; [Ezati \& Agh-Atabaei; 2014] An analysis of towed active construction of the Bojnourd Basin ...; [Giaconia et al.; 2012] Geomorphic evidence of active tectonics ...; [Gurabi \& Emami; 2017] Neotectonics influences on morphological variations ...; [Haghipour \& Burg; 2014] Geomorphological analysis of the drainage ...; [Jamieson, et al.; 2004] Tectonic forcing of longitudinal valleys in the Himalaya ...; [Keller \& Pinter; 2002] Active tectonics, Earthquakes, Uplift ...; [Nakhaei \& Ghanavati; 2006] Application of hyssometric curves in determining areas under erosion and sedimentation ...; [Pedrera, et al. 2009] Testing the sensitivity of geomorphic indices ...; [Pourkermani \& Solgi; 2009] Morphotectonics ...; [Rockwell, et al.; 1985] Tectonic geomorphology of alluvial fans and mountain ...; [Rustaei \& Agh-Atabaei; 2015] Quantitative analysis of the impact of neo tectonic activity ...; [Ruszkiczay-Rüdiger, et al.; 2009] Discrimination of fluvial, eolian and neotectonic features in a low ...; [Salari \& Moradi; 2009] Application of dimensionless hypsometric curves in evaluation of erosion ...; [Singh; 2009] Hypsometry and erosion proneness: a case study in the lesser ...; [Strahler; 1952] Hypsometric (area-altitude) analysis of erosional ...

\section{Article History}

Received: July 17, 2018

Accepted: October 4, 2018

ePublished: December 09, 2018

Copyright $(2018$. This open-access article is published under the terms of the Creative Commons Attribution-NonCommercial 4.0 International License which permits Share (copy and redistribute the material in any medium or format) and Adapt (remix, transform, and build upon the material) under the Attribution-NonCommercial terms. 
Pourzare M. MA

Seif A. PhD

a.seif@geo.ui.ac.ir

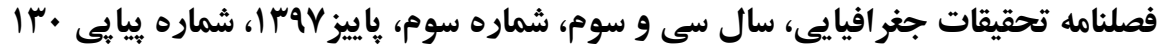

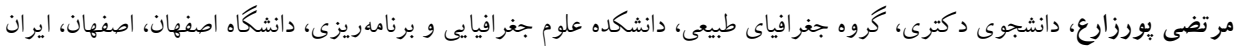

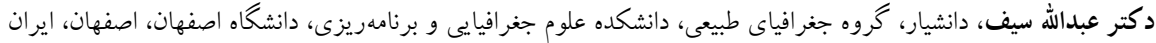

\title{
ارزيابى مساحتهاى در حال فر سايش و رسوبكذارى حوضههاى زمكشى سواحل مكران با استفاده از منحنى هاى هييسومترى بعبعد
}

\author{
دريافت مقاله:M
}

DOI: $10.29252 /$ geores.33.3.170

جكيده

مقدمه: شاخصهاى كمى زئومورفيكى براى شناسايى خصوصيات خاص يكى ناحيه بهويزه در مطالعات تكتونيكى مفيد

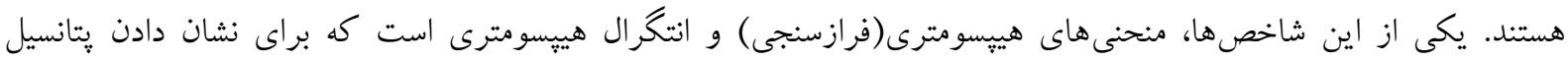

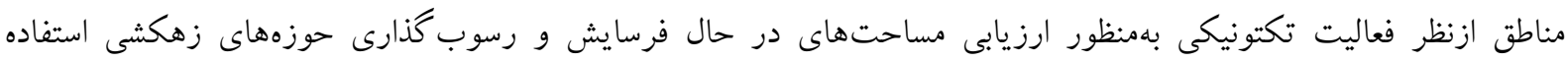

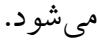
هدف: اين تحقيق بررسى مشخصههاى فيزيكى حوضههاى آبريز سواحل مكران ازنظر ويزگىهاى فرسايشى و رسوبگذارى آنها با استفاده از منحنىهاى هييسومترى بىبعد مىباشد. مواد و روشها: در اين تحقيق براى استخراج شبكه آبراهها و رتبهبندى آنها از مدل رقومى ارتفاعى منطقه باقدرت

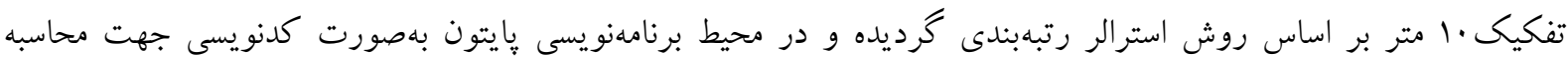
مقادير جداول و ترسيم منحنى هاى هييسومترى بىبعد براى تحليل وضعيت فرسايش و رسوب گذارى در سطح كل حوزه آبريز سواحل مكران و نيز زير حوزههاى زهكشى انجامشده است. نتيجه گيرى: اندازه گيرى شاخص منحنى هييسومترى نشان مىدهد كه در حوضهى اصلى فرآيندهاى زئومورفولوزيكى بهصورت متعادل عمل مى كنند. با توجه مقادير جدول و ترسيم منحنى هييسومترى كل حوضه منطقه نشاندهنده گسترش متعادل

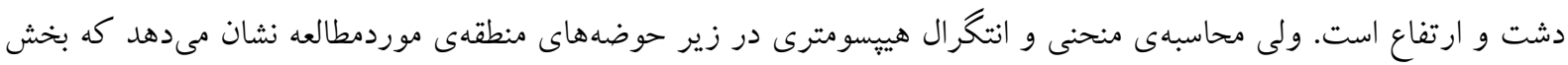

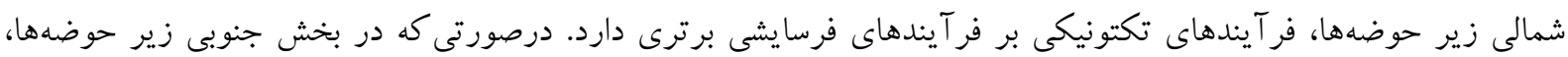

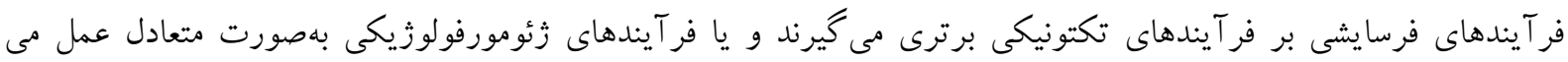

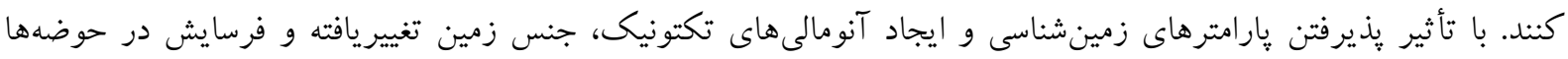

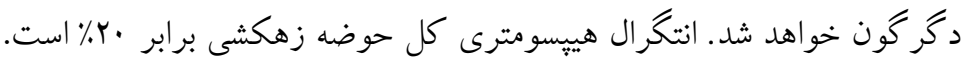

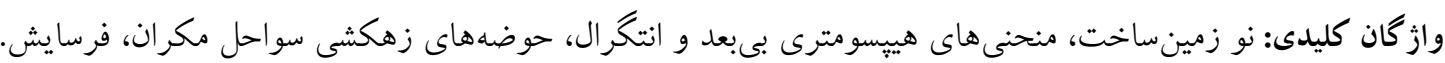

رابطه بين فرم و فرآيند در زئومورفولوزى از اهميت زيادى برخوردار است. با تغيير فرآيند، فرمها تغيير كرده و

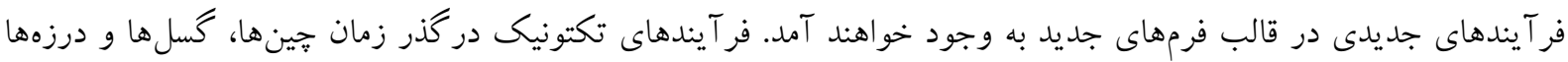
را به وجود مى آوردند. حوضههاى آبريز و اشكال شبكه زهكشى نيز از فرمهاى منتج از فر آيندهاى بيرونى و درونى هستيند. 
IT/ IVT شناسايى فرمها و تغييرات آنها در زئومورفولوزى كمى زيادى در شناسايى نوع فرآيندها و تغييرات آنها خواهد كرد كه در اين راستا دانش زئومورفومترى و مورفومترى نقش خود را ايفا مى كنند (Gurabi \& Emami, 2017).

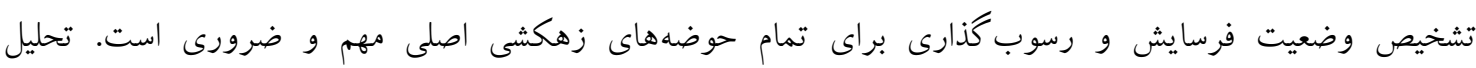
هييسومترى بهعنوان يك شاخص براى مراحل فرسايش حوضههاى زهكشى به كاربرده مىشود (Singh, 2009). انتكرال

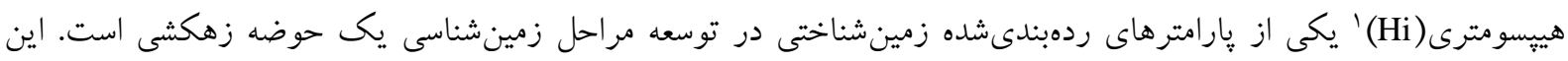

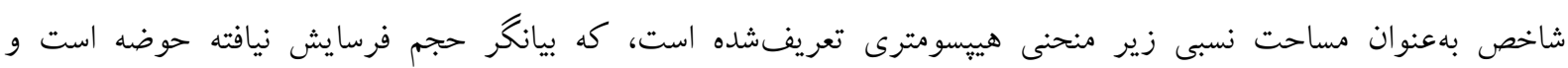

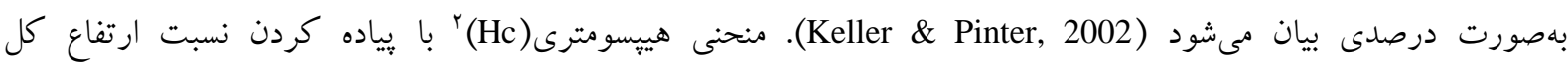
حوضه (ارتفاع نسبى) در مقابل نسبت مساحت كل حوضه حاصل مىشود (Strahler, 1952).

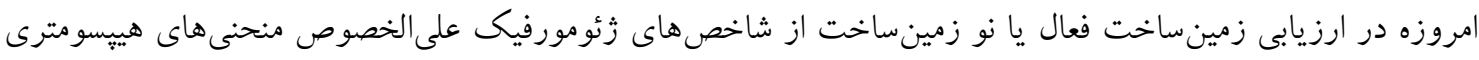

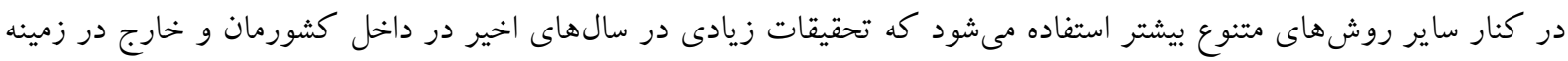

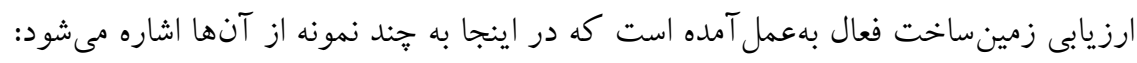

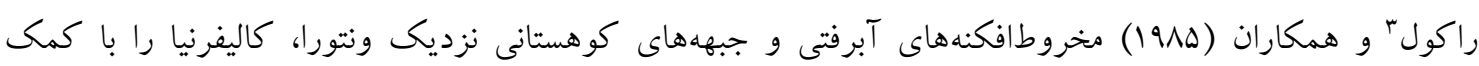

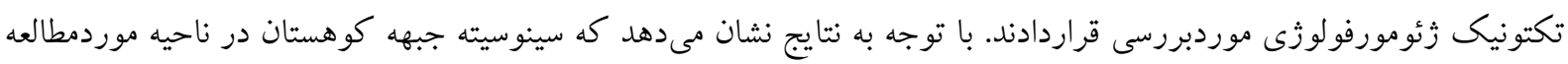

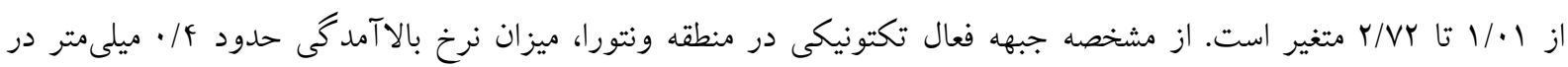
سال است (Rockwell, Keller, \& Johnson, 1985).

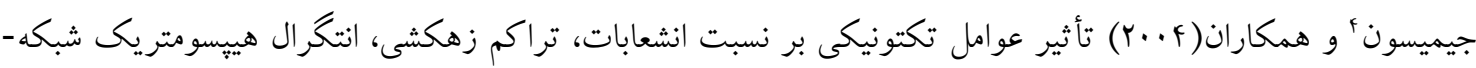

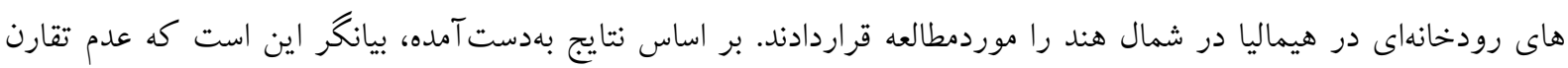

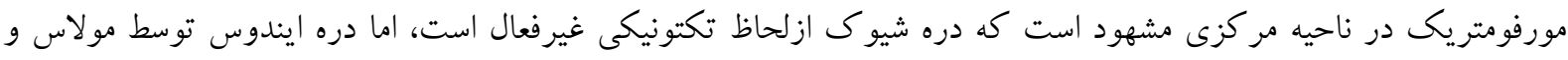
باتوليت به سمت شمال شرقى محصور شده است (Jamieson, Sinclair, Kirstein, \& Purves, 2004).

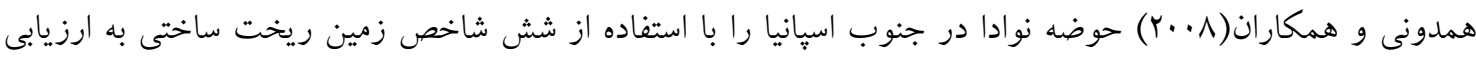

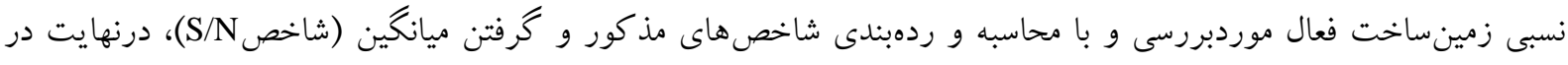

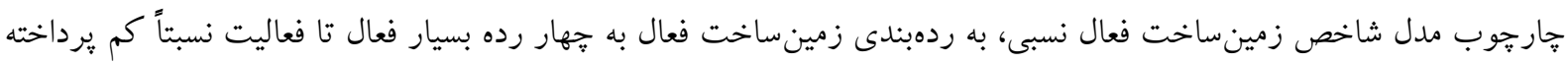

است (El Hamdouni, Irigaray, Fernández, Chacón, \& Keller, 2008).

ده بزرگى و همكاران(·(Y.1)، با استفاده از شاخصهاى زئومورفيك ناحيه سروستان در بخش زاكرس مركزى را

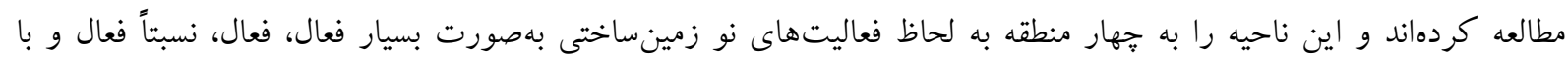
فعاليت بسيار پايين طبقهبندى نمودهاند (Dehbozorgi et al., 2010).

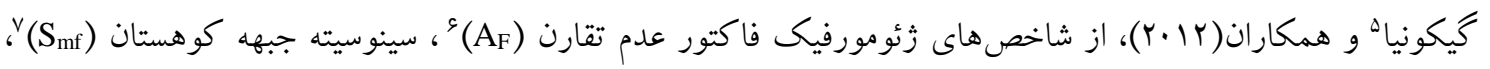

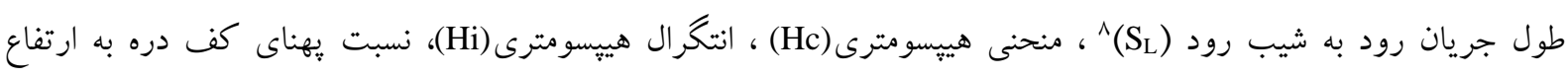
دره(VF) براى بررسى تغيير شكل آبراههها و دامنههاى سيرا در جنوب شرق اسيانيا بر اثر فعاليتهاى زمينساختى استفاده

\footnotetext{
1 hypsometric integral

2 hypsometric curves

3 Rockwell

4 Jamieson

5 Giaconia

6 Asymmetry Factor

7 Sinuosity of Mountain-Frount

8 Stream Length- Gradient Index

9 Valley Floor Index
} 
ارزيابى مساحت هاى درحال فرسايش و رسوبگذارى حوضه هاى زهكشى .../ IVT

DOI: 10.29252/geores.33.3.170

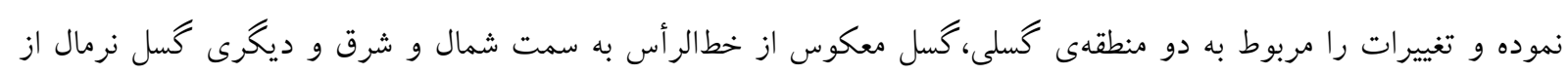
خطالر أس بهطرف جنوب مى دانند (Giaconia et al., 2012).

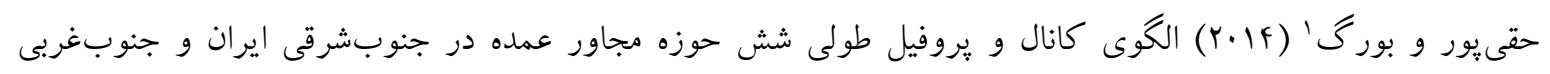
يا كستان در راستاى انعكاس رشد اخير و فعال گوه برافزايشى مكران موردبررسى قرار دادهاند (Haghipour \& Burg, 2014).

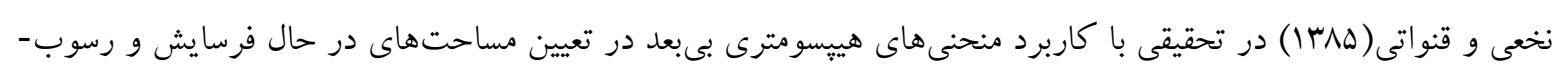

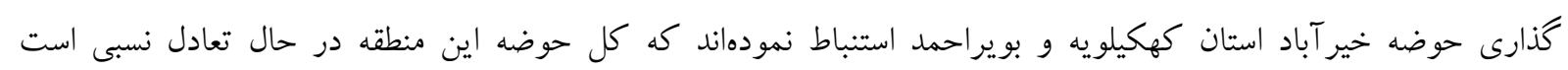

.(Nakhaei \& Ghanavati, 2006)

سالارى و مرادى(MMM|) مساحتهاى در حال فرسايش و رسوب گذارى حوضه آبخيز بانه را با استفاده از منحنىهاى

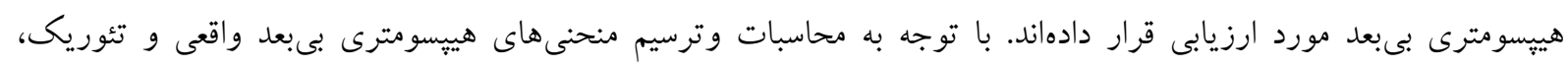

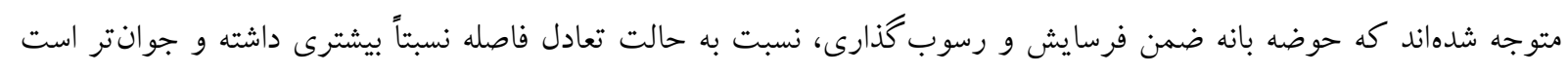

.(Salari \& Moradi, 2009)

عزتى و آق آتاباى(بوسبا) شاخص هاى مختلف شامل عدم تقارن حوضه زهكشى، شكل حوضه، منحنى هييسومترى و انتكرال

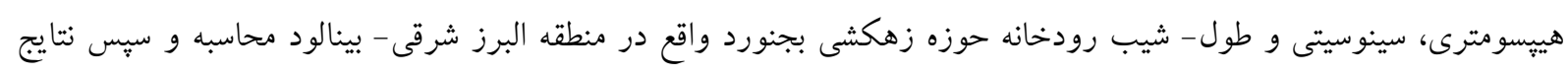

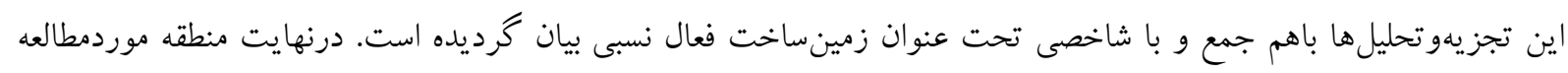

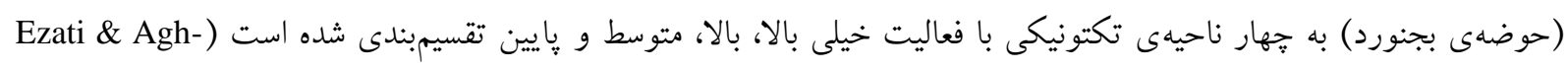

(Atabaei, 2014

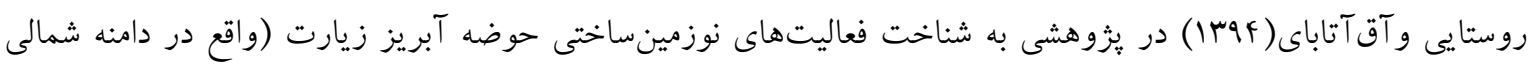

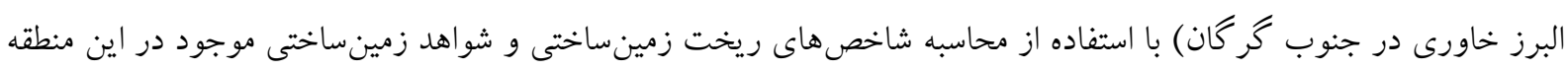

يرداخته است (Rustaei \& Agh-Atabaei, 2015).

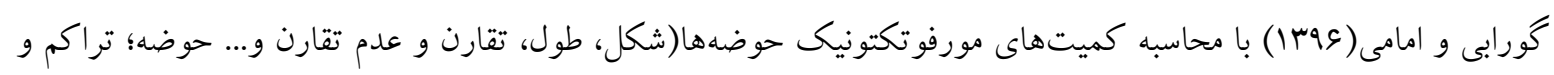

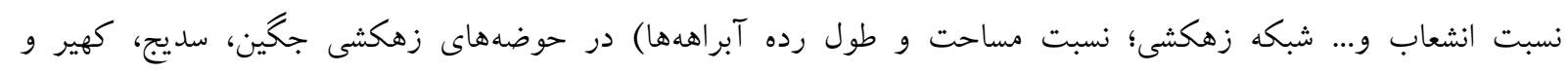

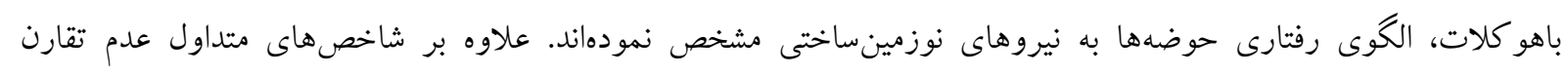

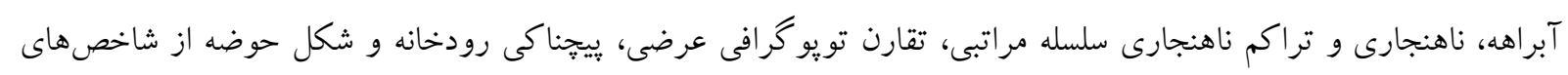

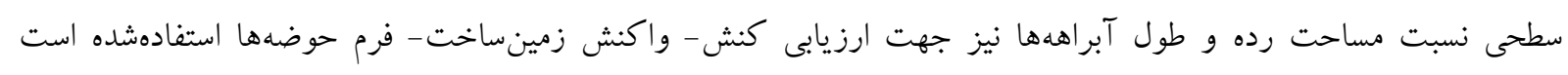

.(Gurabi \& Emami, 2017)

اين يزوهش از اين لحاظ حائز اهميت است كه تاكنون تحقيقى بيرامون ميزان فعاليت زمينساختى در ارزيابى مساحت-

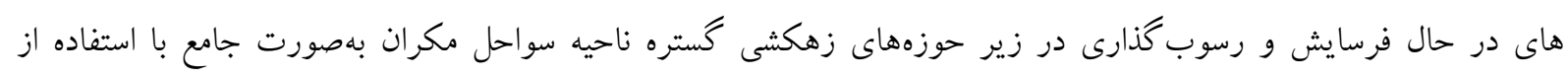

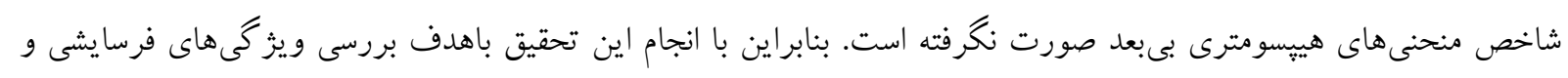

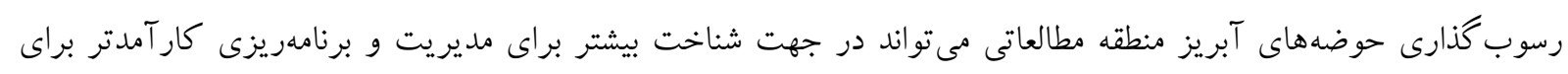
توسعه پايدار صورت بكيرد.

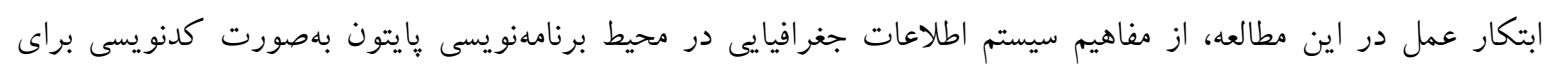

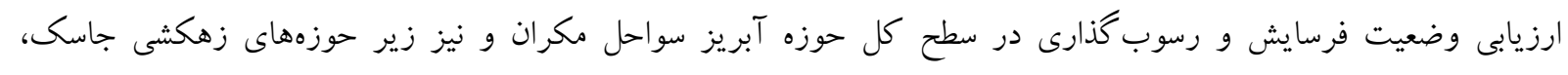


IT / IVF جگين، كابريك، سديج، فنوج، نيكشهر و باهو كلات منطقه جهت محاسبه مقادير جداول و ترسيم منحنىهاى هييسومترى بىبعد

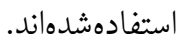

\section{محدوده و زير حوضههاى منطقه مطالعاتى}

حوضه آبريز منطقه مطالعاتى، زير حوضه آبريز خليجفارس و درياى عمان مىباشد كه از شرق به مرز پاكستان و از

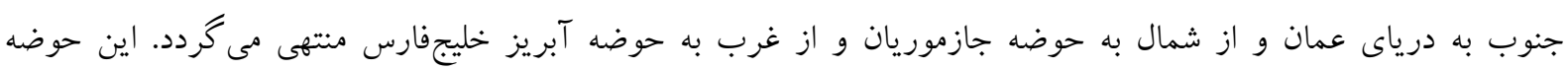

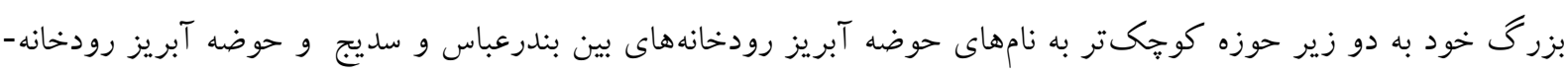

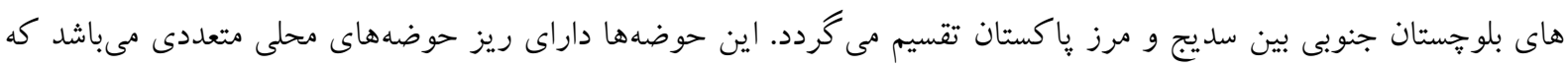

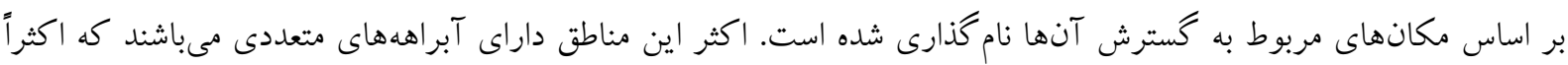

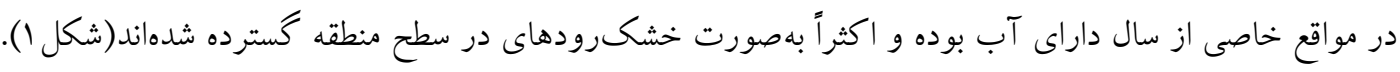

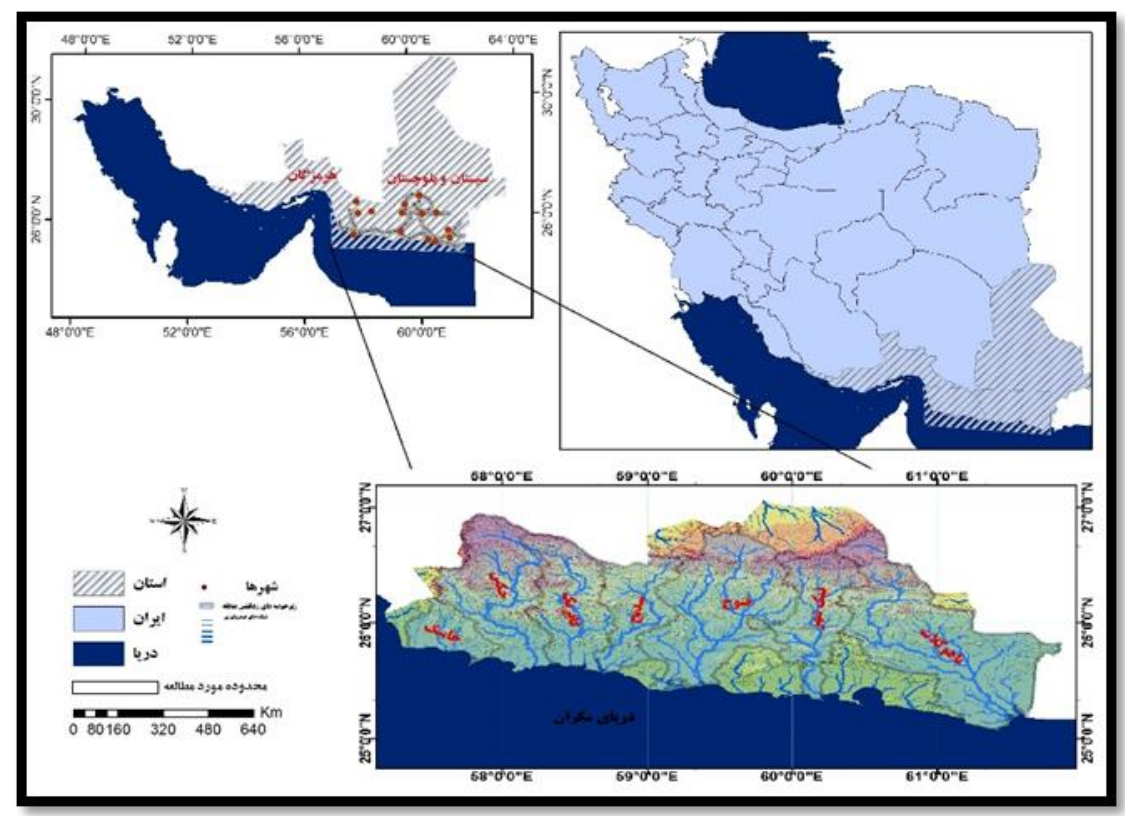

شكل 1- نقشه موقعيت زير حوضههاى آبريز منطقه مطالعاتى

حوضه آبريز رودخانههاى بلو جستان جنوبى بين سديج و مرز پا كستان

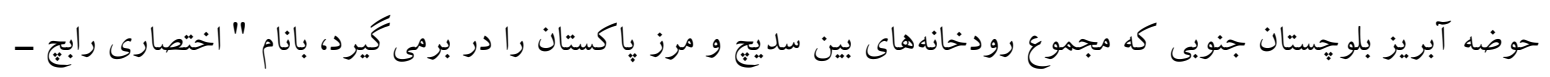

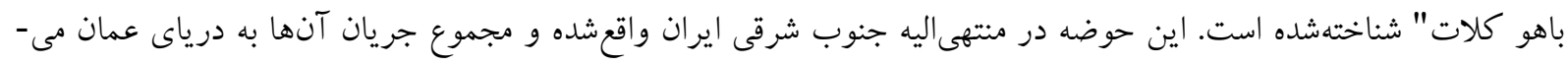

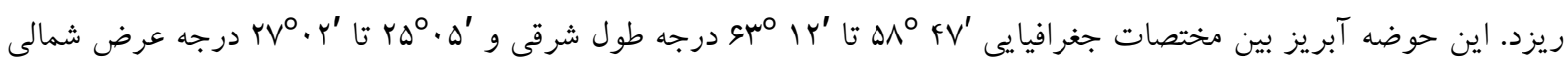

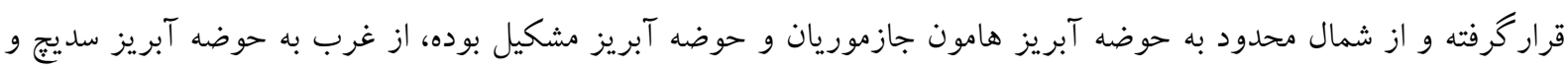

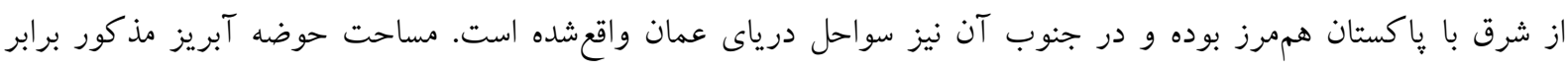

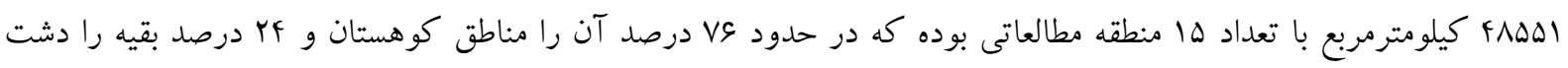

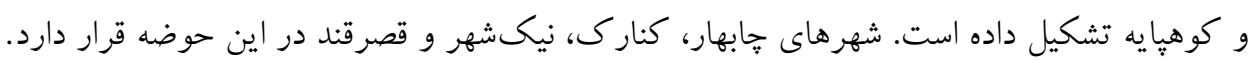


حوضه آبريز رودخانه هايى كه بانام اختصارى "بندرعباس - سديج " شناخته مى شود شامل مجموعه رودخانهايى است كه از شرق حوضه آبريز رودخانه كل شروعشده و در حد شرقى حوضه آبريز رودخانه سديج خاتمه مىيذيرد. حوضه آبريز

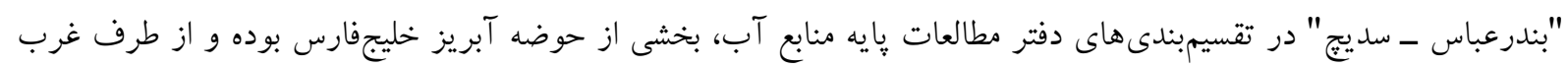
به حوضه آبريز رودخانه كل، از شمال به حوضه آبريز هامون جازموريان، از شرق به حوضه آبريز بلوجّتان جنوبى و از جنوب به خليجفارس و درياى عمان محدود كرديده است. اين حوضه آبريز در بخش ميانى حوضههاى مجاور خليجفارس قرار داشته و زهكشى آب سطحى و زيرزمينى آنها به سمت خليجفارس و درياى عمان مىباشد. اين حوضه آبريز بين مختصات جغرافيائى 政 $\Delta \Lambda^{\prime}$ Y M منطقه مطالعاتى بوده كه در حدود Yr درصد آن را مناطق كوهستانى و M درصد آن را دشتها و كوهيايه تشكيل داده است. شهرهاى بندرعباس، ميناب، رودان و جاسك در اين حوضه آبريز واقعشه و بخشى از جاده اصلى بندرعباس به سيرجان و

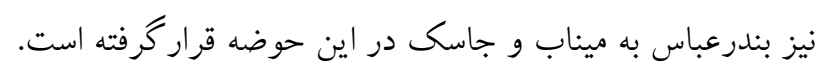

مواد و روشها

در اين تحقيق با بهره گيرى از نرمافزار ArcGIS در محيط Arcmap نقشهاى تويو گرافى .....ه: ا، نقشههاى زمينشناسى

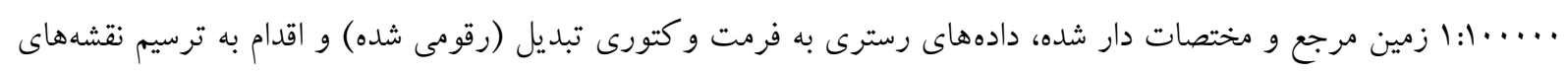
محدوده مطالعاتى كرديد. براى استخراج شبكه آبراههها و رتبهبندى آنها براى استفاده در محاسبات شاخص منحنىهاى ارتفاعى دهى هيدرولوزى، از مدل رقومى ارتفاعى منطقه( DEM)' و بر اساس روش استرالرَّاز ا تا ها رتبهبندى شد(شكل r).

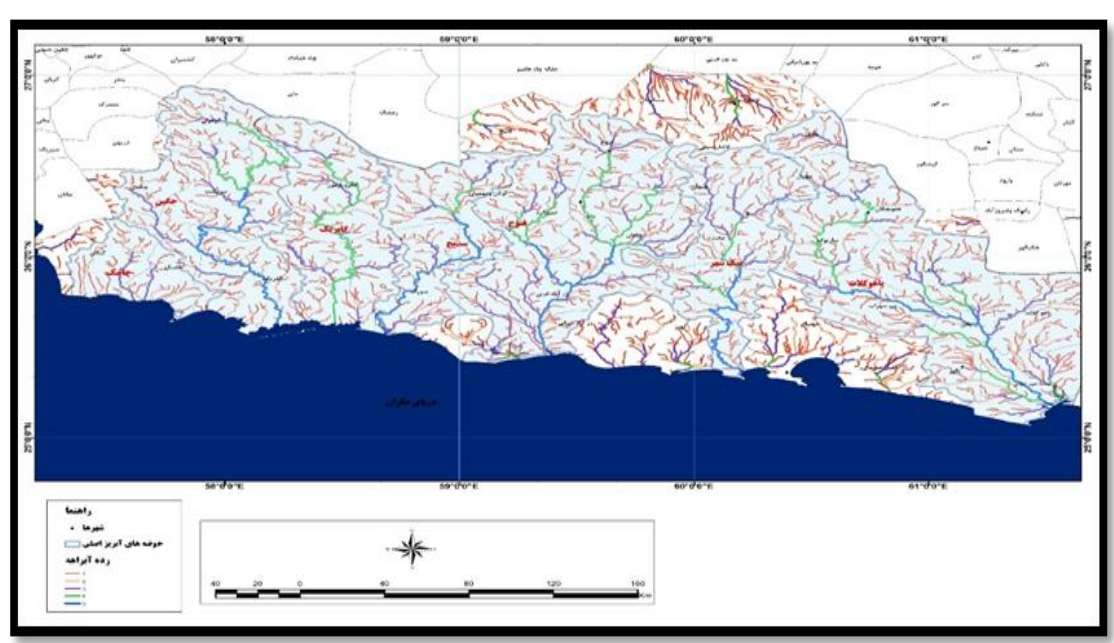

\section{شكل r- رده آبر اهلها در حوضههاى زهكشى منطقه بر اساس روش استر الر}

جهونكى انجام فر آيند آمادهازى لايه شبكه زهكشى با كمك اكستنشن ArcHydro در محيط ArcMap و با استفاده از DEM 

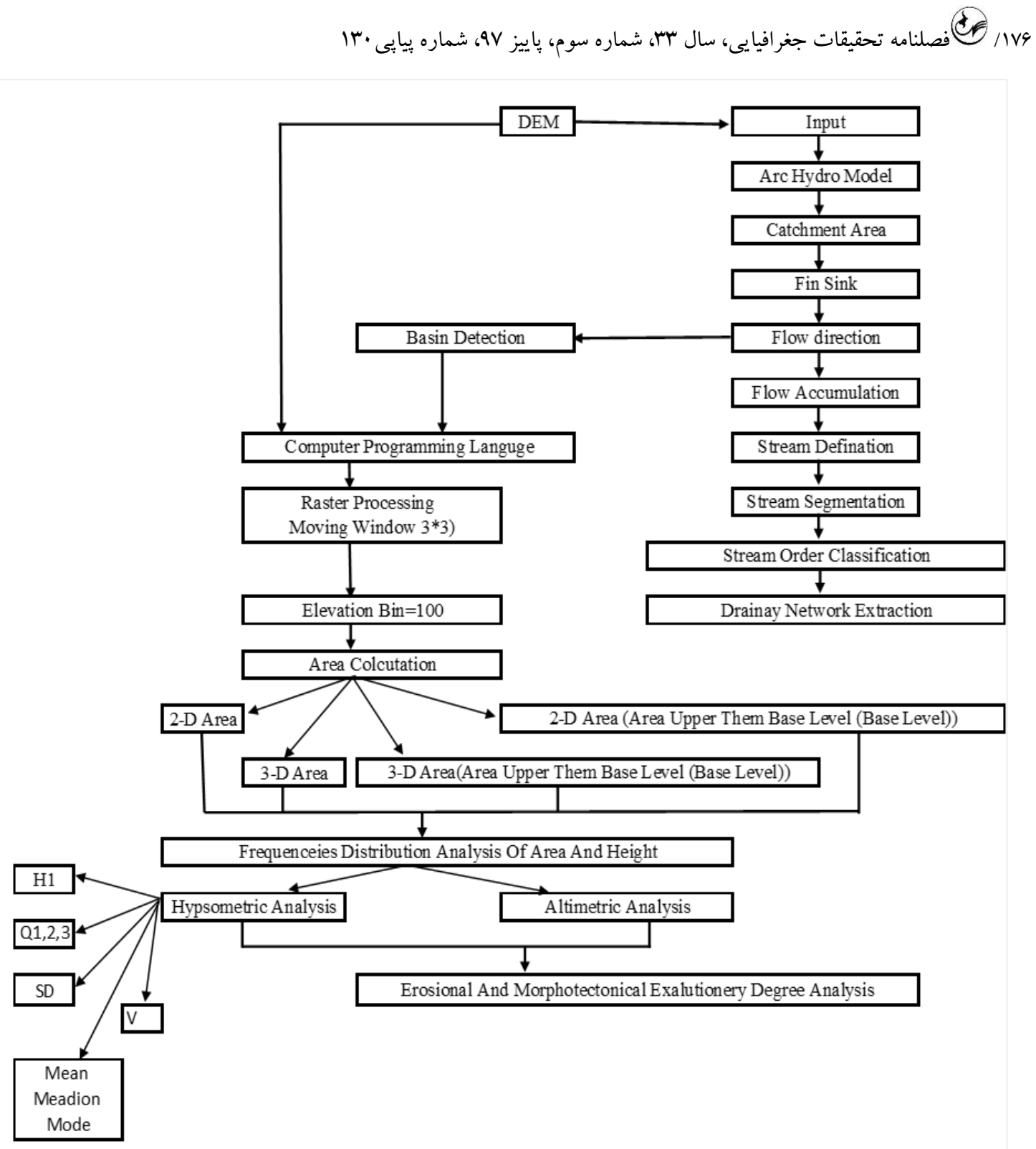

شكل r- الكوريتم استخراج شبكه زهكشى و دادههاى مورفومترى زير حوضههاى آبريز منطقه مطالعاتى

$$
\text { منحنى هاى هيبسو مترى وانتخرال هيبيو مترى }
$$

اين منحنىها يراكندگى ارتفاعات را در بخشى از يهناى يكى حوضه زهكشى به كل وسعت حوضه را تشريح مى كند (شكل F).

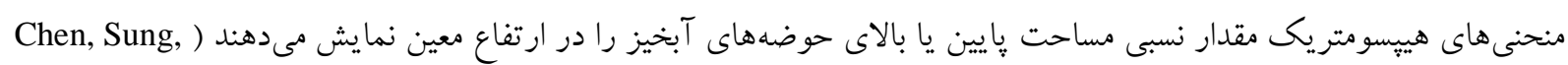
.\& Cheng, 2003

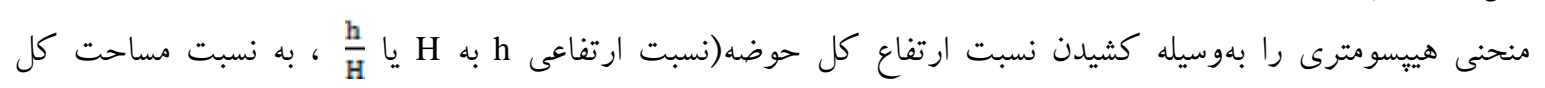

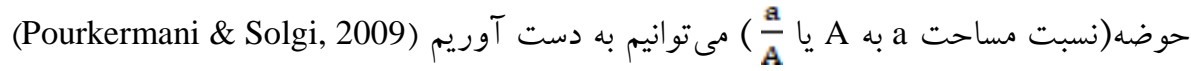

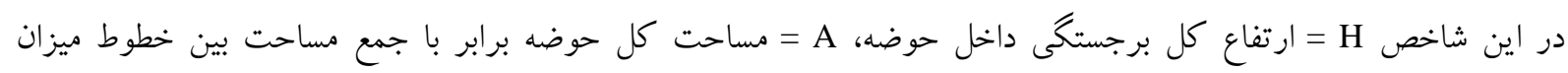
موجود در حوضه مىباشد و a = مساحتى از حوضه كه بالاتر از ارتفاع(h) قرار دارد. 

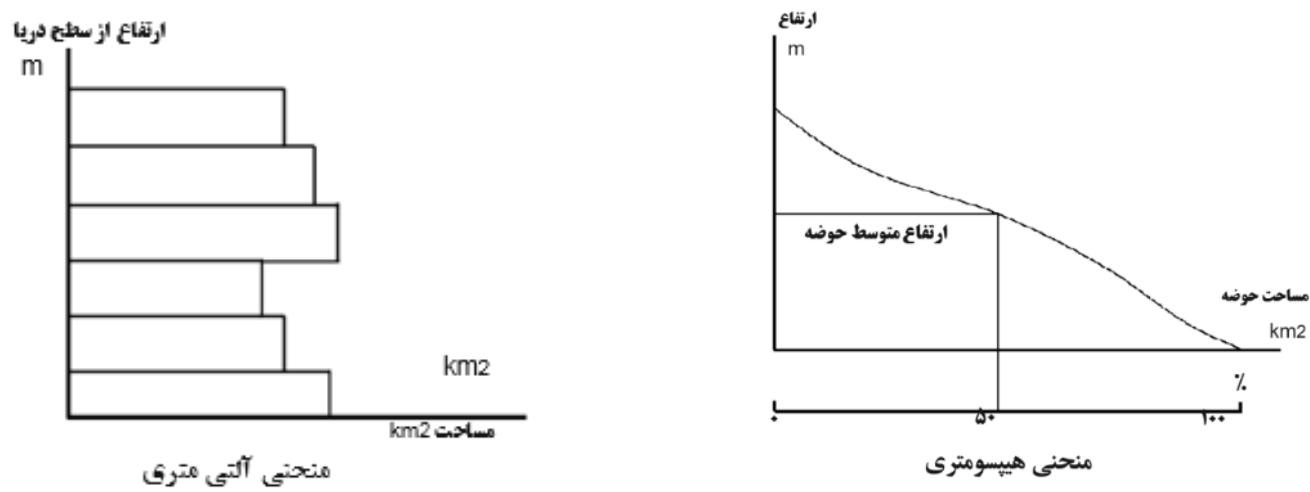

\section{شكل + - منحنى هاى هييسومترى و آلتى مترى حوزه زهكشى}

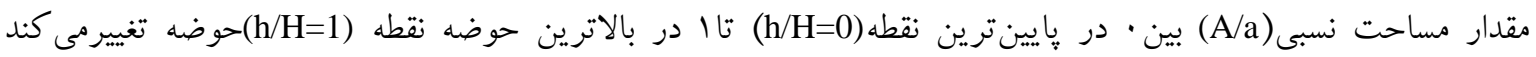

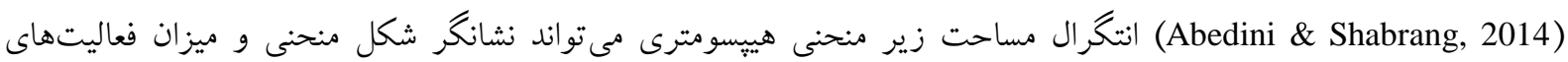

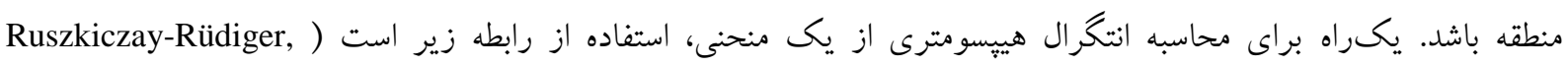

(Fodor, Horváth, \& Telbisz, 2009

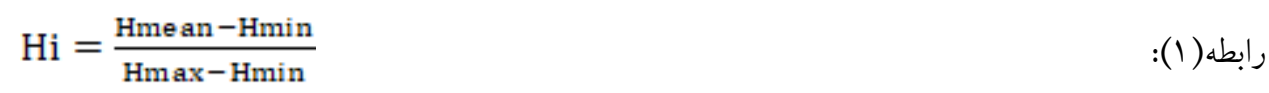

در معادله بالا Hi = انتخرال هييسومتريك؛ Hmean= ارتفاع متوسط حوضه؛ Hmin = حداقل ارتفاع حوضه و =

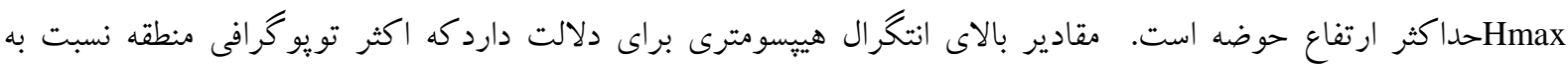
ارتفاع ميانگين بلندتر است، مثلاً ارتفاع بلند و مسطح آن بهوسيله يكى رودخانه عميق حفرشده است، نشانكر تكتونيك فئ فعال

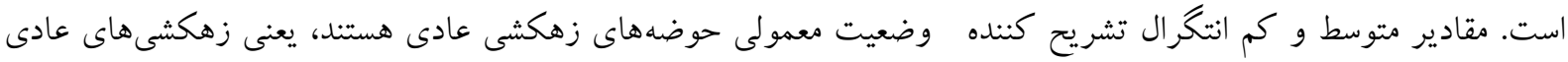

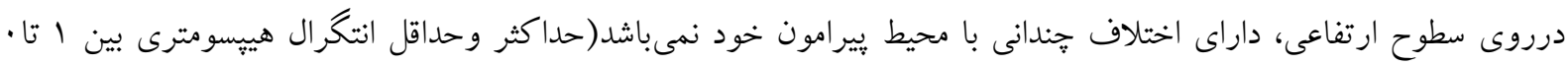

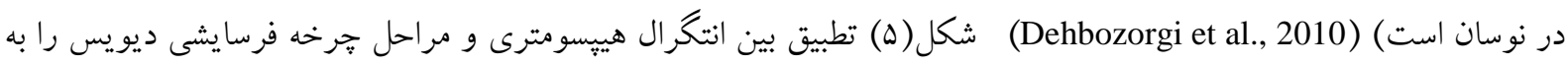

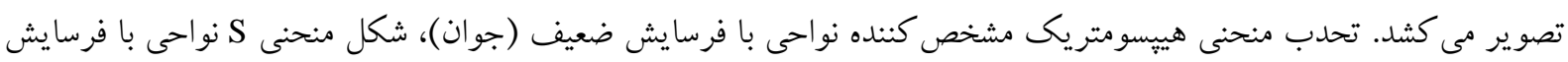

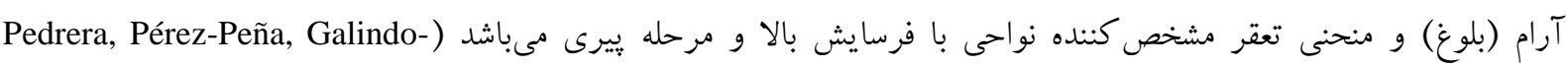
(Zaldívar, Azañón, \& Azor, 2009

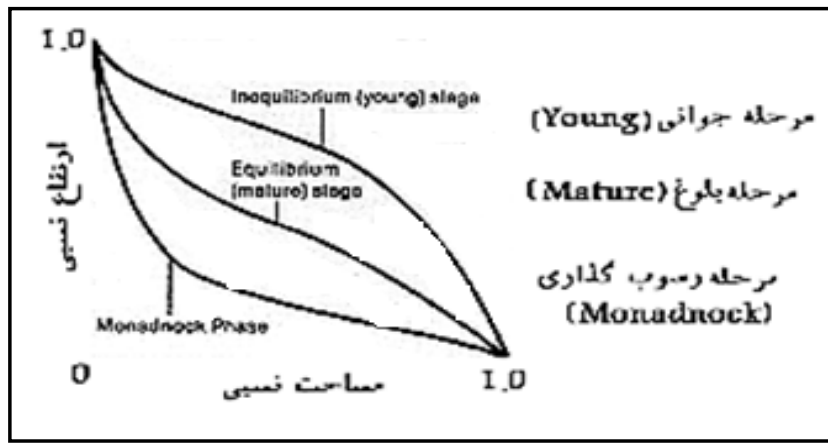

شكله- سه حالت از منحنى هييسومترى

در اين يزوهش براى محاسبه مقادير با استفاده از مفاهيم سيستم اطلاعات جغرافيايى در محيط برنامهنويسى هايتون بهصورت

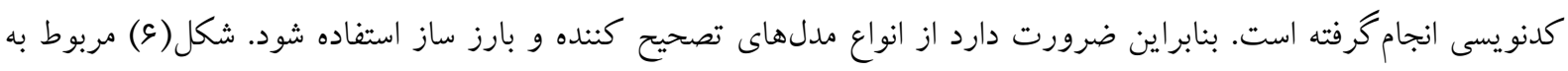

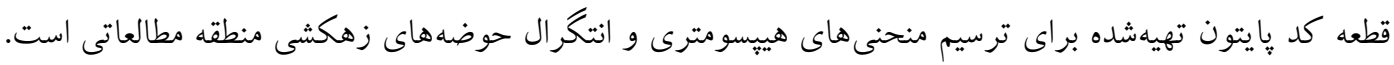




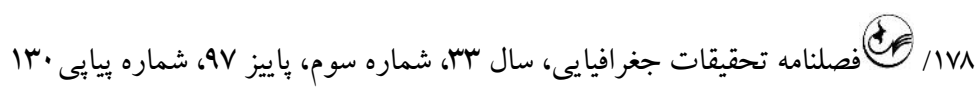

\begin{tabular}{|c|c|}
\hline 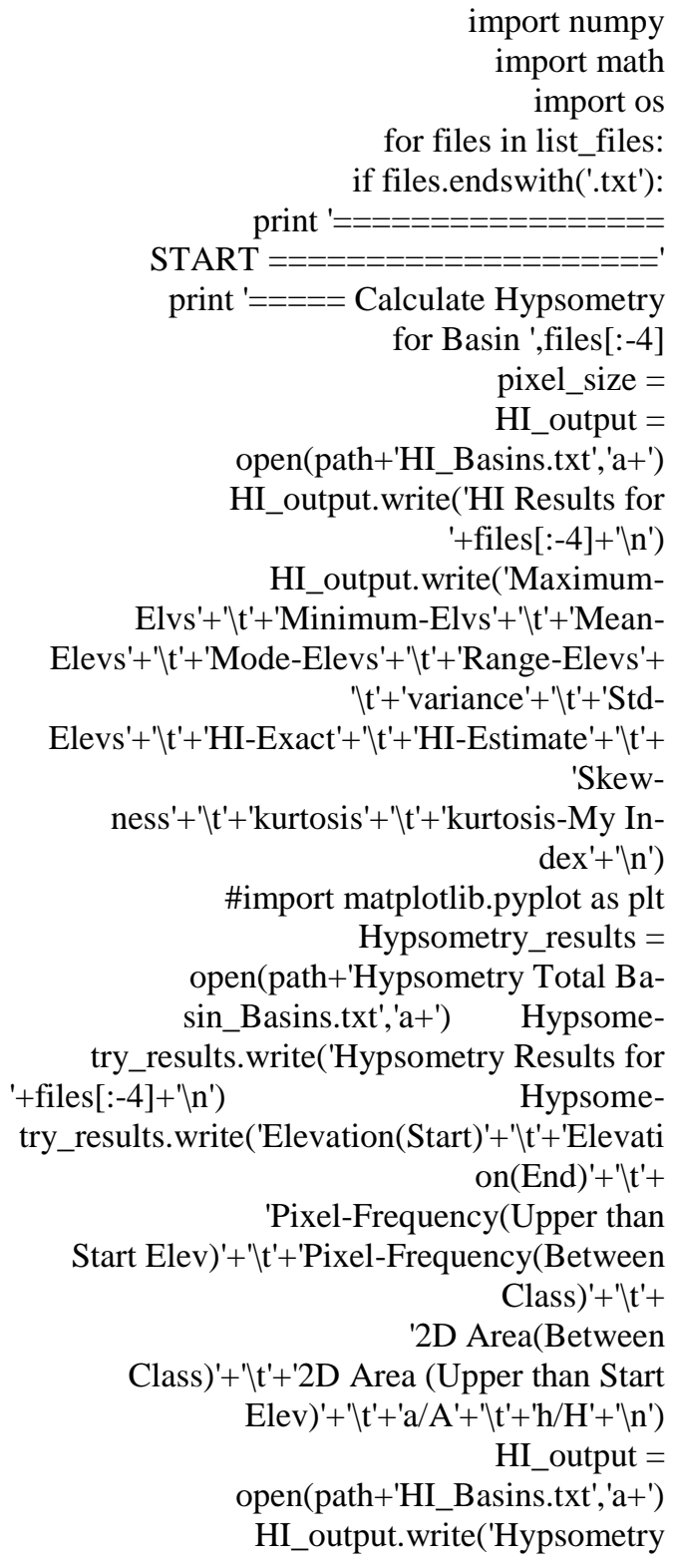 & 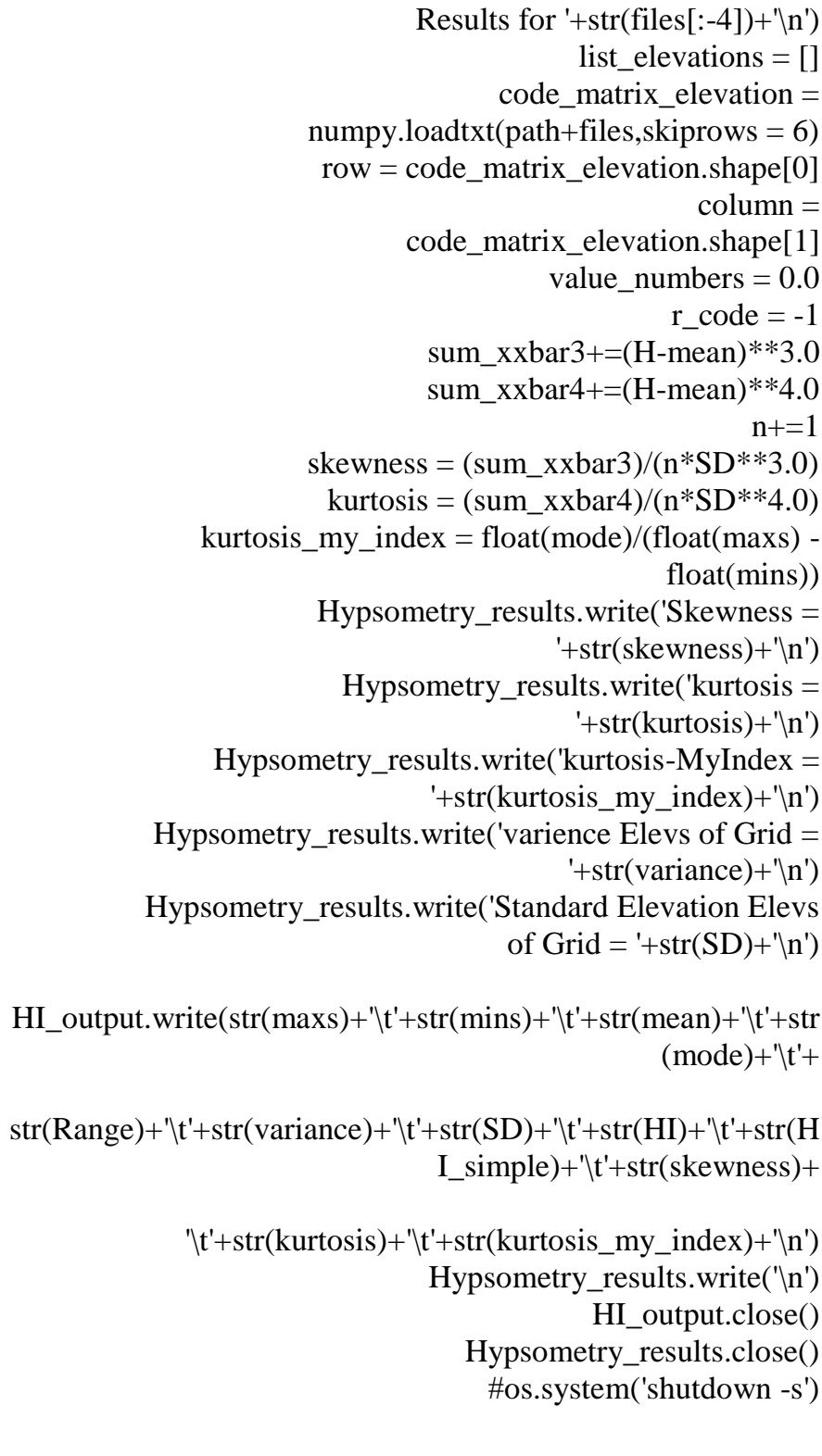 \\
\hline
\end{tabular}

شكل צ- بخشى از كد پايتون براى ترسيم منحنى هيبسومترىهاى بع بعدحوضه هاى زهكشى منطقه

يافتههاى بزغوهش

جهت تحليل هييسومتريكى زير حوضهها و كل منطقه بر اساس اطلاعات مربوط به مساحتها و ارتفاعات با استفاده از

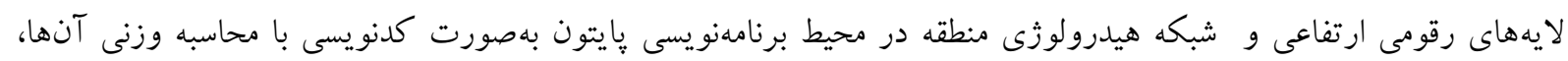

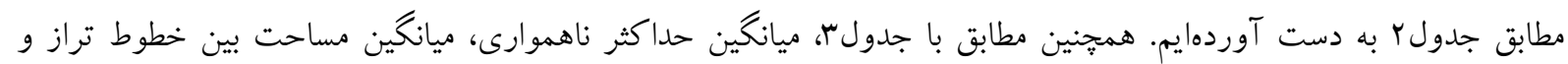

ميانخين نسبت ارتفاعى در زير حوضهولى به دست منطقه محاسبه شده است. 
جدول r- ارقام محاسبه شده مربوط به منحنى هييسومترى بعبعد براى كل حوضه زهكثى منطقه

\begin{tabular}{|c|c|c|c|c|}
\hline m ارتفاع & اختلاف ارتفاع & مساحت Km2 & $\mathrm{a} / \mathrm{A}$ & $\mathrm{h} / \mathrm{H}$ \\
\hline$\Lambda V$ & . & INFV & 1 & . /.YY \\
\hline IAV & $1 \cdots$ & VNI & •/VYM & .1 .91 \\
\hline YAV & r. & sı. & $\cdot / 8.8$ & ./11r \\
\hline HAV & $r .$. & $\Delta \cdot r$ & $\cdot / D \cdot F$ &.$/ 109$ \\
\hline FAV & $f \cdot \cdot$ & F.r & - / FYq & $\cdot / r \cdot \Delta$ \\
\hline$\Delta \wedge \vee$ & $\Delta \cdots$ & $r \Delta \Lambda$ & - /rsq &.$/ T \Delta$. \\
\hline s^V & s.. & Trs & $\cdot / \mu / \Delta$ & . / r9s \\
\hline VAV & $v \cdots$ & ו & - /TSE & $\cdot / \mu F \mid$ \\
\hline$M V$ & $\wedge \cdots$ & rss & $\cdot|r| s$ & $\cdot /$ rAV \\
\hline १४V & $9 \cdots$ & MTV & $.|| 8 \mid$ & س TF/ \\
\hline $1 \cdot 1 \mathrm{~V}$ & $1 \cdots$ & MIs &.$/ 11 r$ & $\cdot / F V \Lambda$ \\
\hline $111 \mathrm{~V}$ & $11 \cdots$ & 101 & $\cdot / \cdot \wedge$. & $\cdot / \Delta Y F$ \\
\hline IYAV & $1 Y .$. & Irk & $\cdot / \cdot \Delta V$ &.$/ 059$ \\
\hline IrAV & $1 \mu .$. & 98 & $\cdot / \cdot M V$ &.$/ 810$ \\
\hline IFAV & $1 f \cdots$ & 99 & /. &.$|88|$ \\
\hline $10 \wedge \mathrm{V}$ & $10 \ldots$ & ff &.$/ \cdot 1 r$ & $\cdot / V \cdot G$ \\
\hline ISAV & 16. & rr & $\cdot / \cdots c$ & - /VQr \\
\hline IVAV & $1 V \cdot$ & Ir & $\cdot / \cdots r$ & -/V9V \\
\hline IMV & $11 \cdots$ & $s$ & $\cdot / \cdots 1$ & . /AFH \\
\hline $191 \mathrm{~V}$ & $19 .$. & r & $\cdot / \cdots$ & $\cdot / M M 9$ \\
\hline$r \cdot \Lambda V$ & r... & . & $\cdot / \ldots$ &.$/ 9 M_{F}$ \\
\hline
\end{tabular}

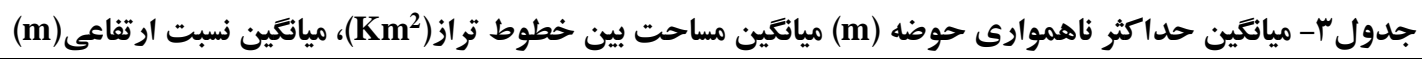

\begin{tabular}{|c|c|c|c|c|}
\hline ميانگين نسبت & ميانگين مساحتهاى & ميانخين حداكثر ارتفاع ناهموارى & ريز حوضههاى زهكشى & رديف \\
\hline$\cdot / F V Y$ & $|\varepsilon| / s \wedge$ & v. & جاسك & 1 \\
\hline$\cdot / F V D$ & YMI/T. & $9 \ldots$ & سديج & r \\
\hline$\cdot / F \wedge V$ & $m_{F} \cdot / 11$ & $11 \ldots$ & جخين & r \\
\hline$\cdot / F A I$ & $r \Delta I / \varepsilon_{\Delta}$ & $11 \ldots$ & كابريك & f \\
\hline$\cdot / 4 \wedge 9$ & $01 r / v q$ & $1 \ldots$ & فنوج & $\Delta$ \\
\hline$\cdot / F V A$ & $r F V / q D$ & $1 \cdot 0$. & نيكشهر & $\varepsilon$ \\
\hline$\cdot / F A F$ & STE/DS & $1 \cdot 0$. & باهو كلات & V \\
\hline$\cdot / F V A$ & MIN/IV & $1 \cdot \wedge V$ & كل حوضه & $\wedge$ \\
\hline
\end{tabular}

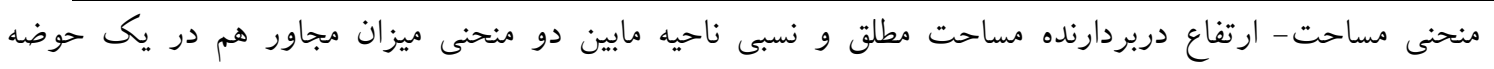

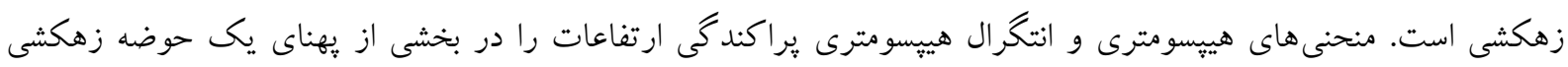




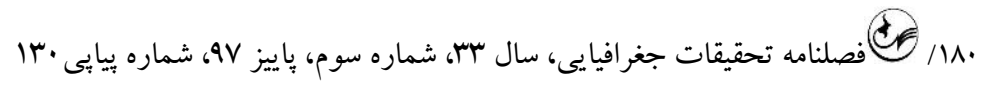

به كل وسعت حوضه را تشريح مى كند. اين منحنى را بهوسيله كشيدن نسبت ارتفاع كل حوضه(نسبت ارتفاعى h به H H به به نسبت

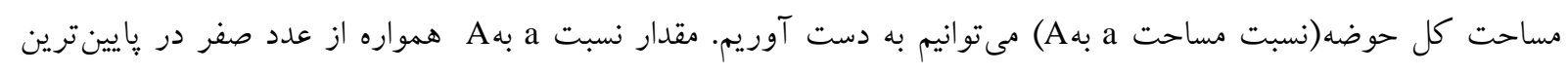

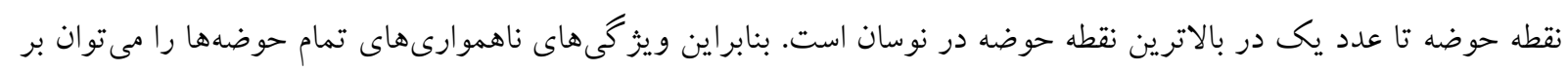

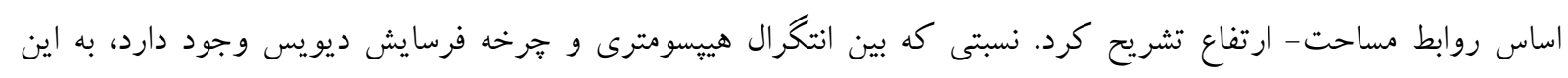

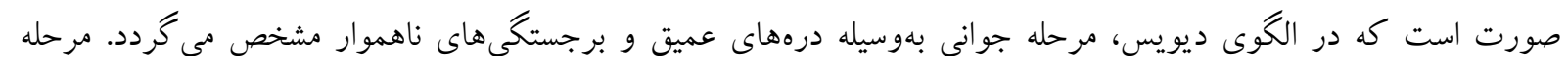

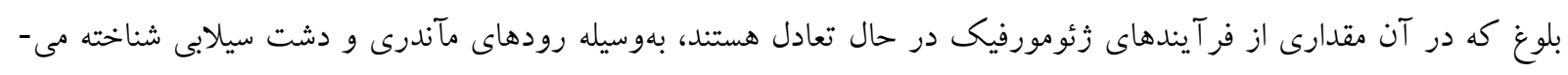

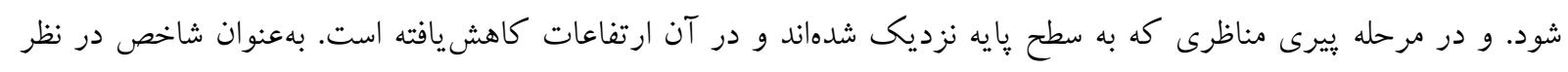

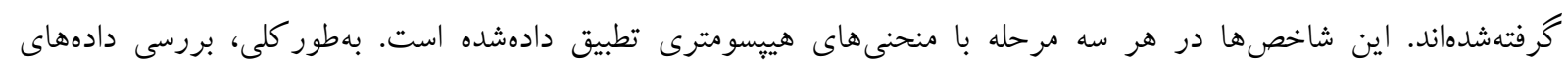

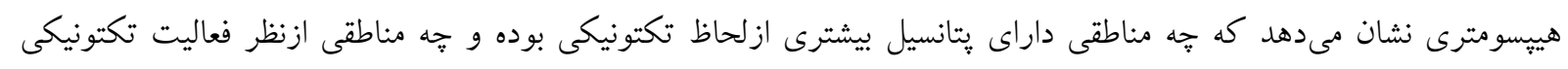

داراى يتانسيل كمترى مىباشند (Pourkermani \& Solgi, 2009).

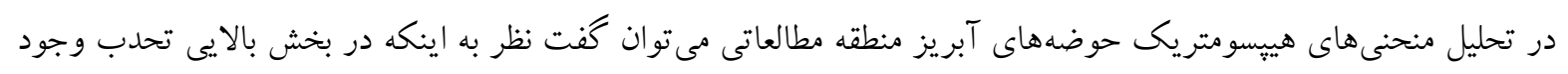

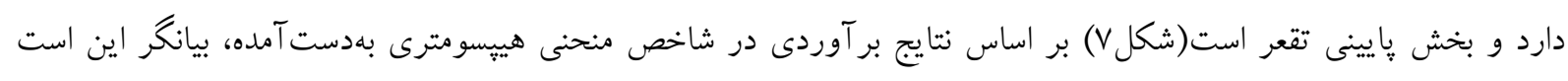

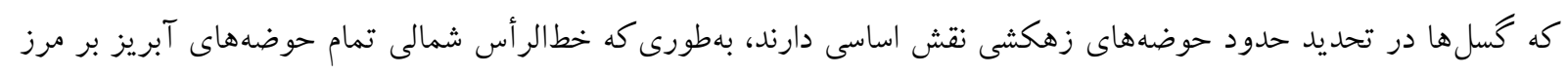
كسلى زونهاى ساختمانى مكران انطباق دارند. 


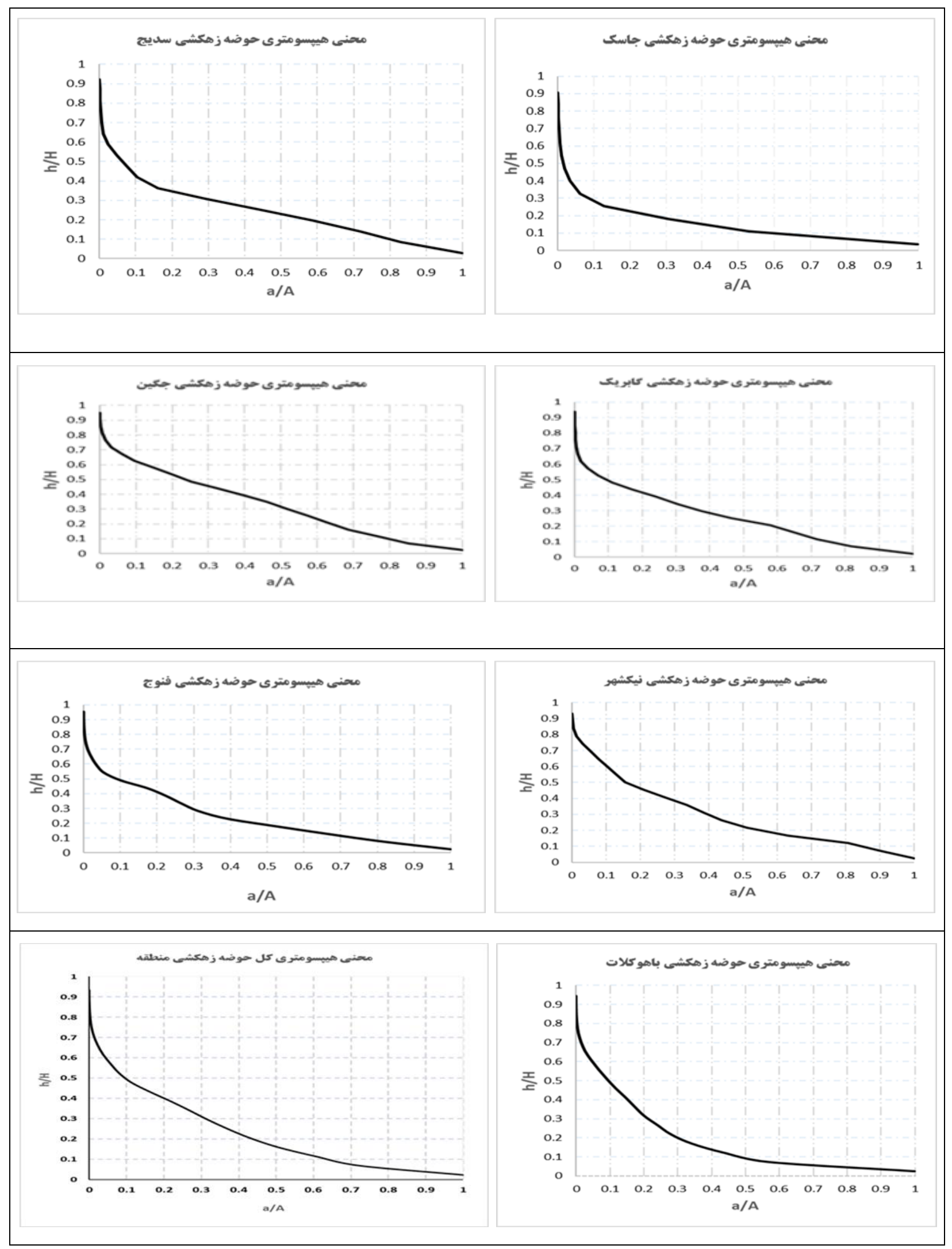

\section{شكل Y - منحنى هييسومترى حوضه هاى زهكشى منطقه مطالعاتى}

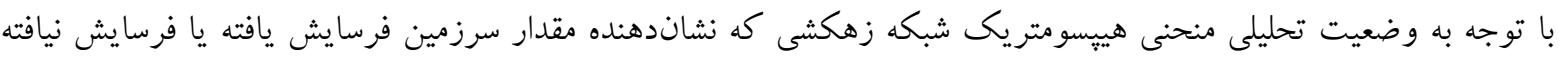

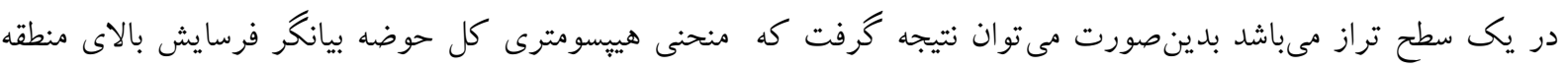




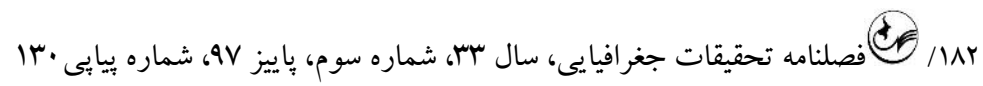
بوده و بر اساس الكوى ديويس، در مرحله بيرى مناظرى كه به سطح پايه نزديك شدهاند و در آن ارتفاعات كاهش يافته است.

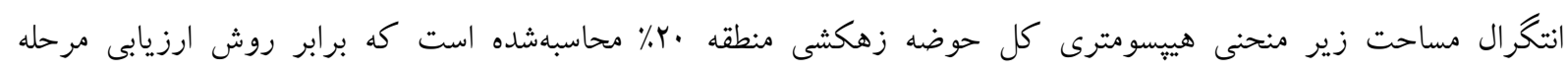

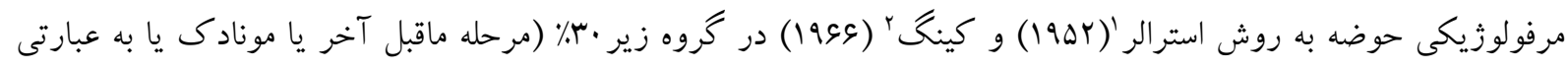

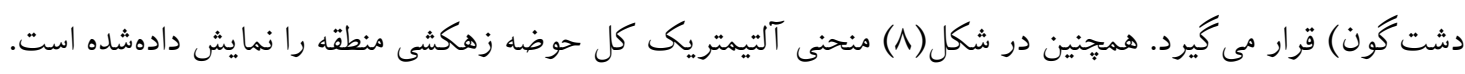

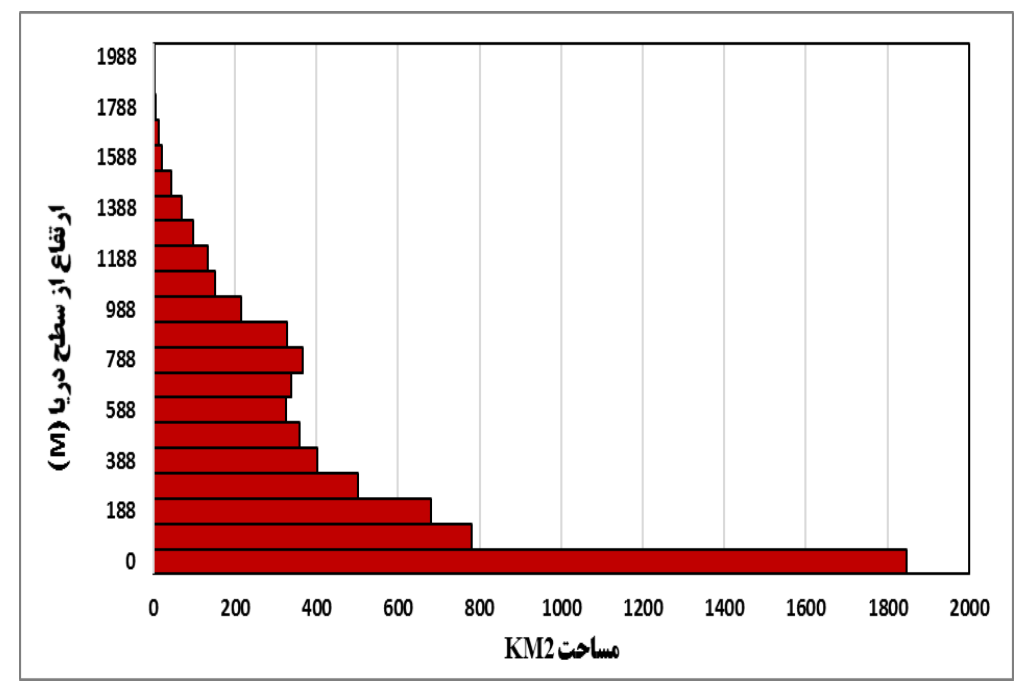

\section{شكل^- منحنى آلتيمترى كل حوضه زهكشى منطقه مطالعاتى}

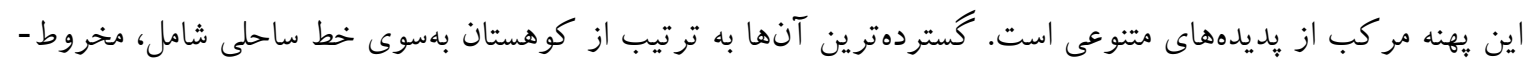

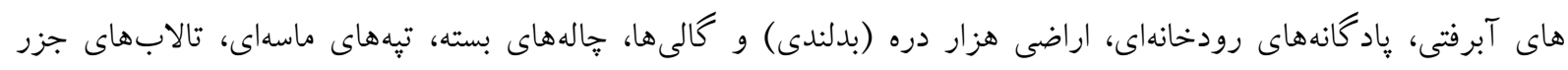

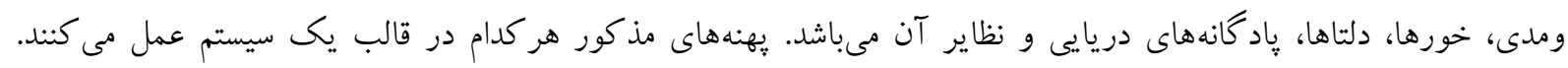

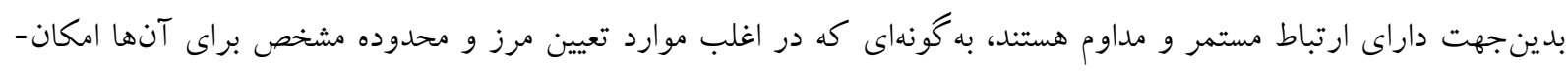
يذير نيست.

كسل هاى سديج، كنار ك، ميناب و نوار ساحلى بهعنوان عوامل زمين ساخت در تعيين ناهموارىها و ساختمان جينهشناسى

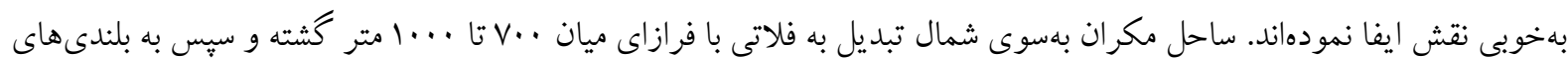

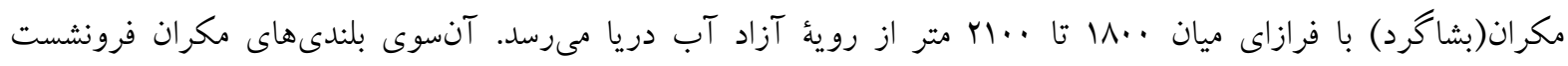

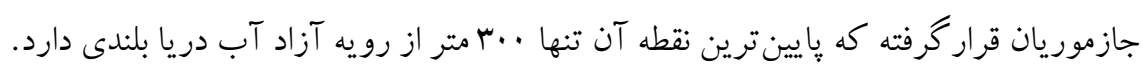

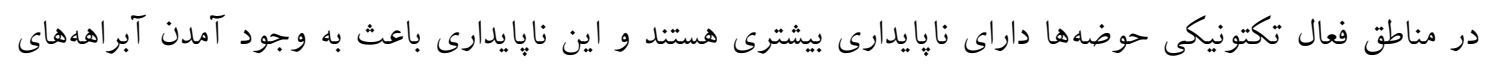

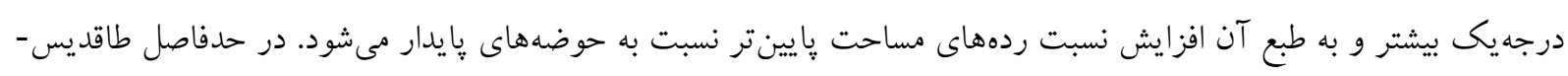

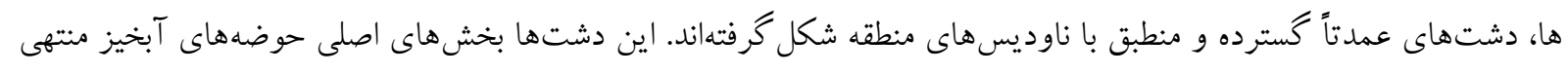

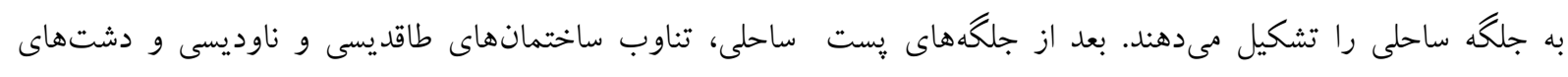

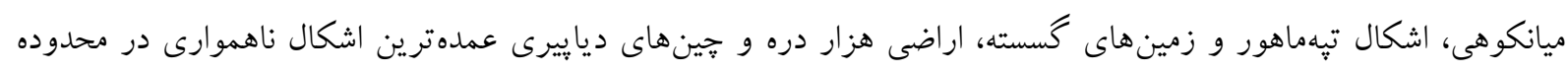
موردمطالعه به شمار مىروند. 
زمانى عوامل بيرونى و زمانى عوامل درونى در ايجاد تغييرات نقش داشتهاند. حتى تغييرات در زيرمجموعه اين عوامل و

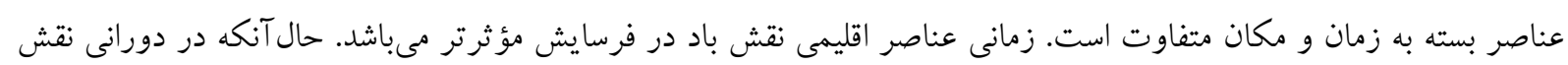

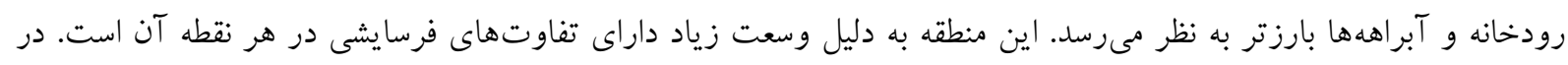

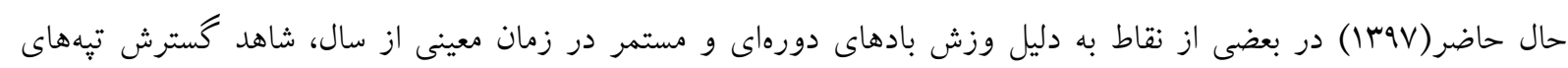

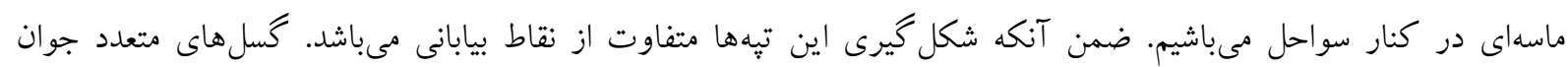

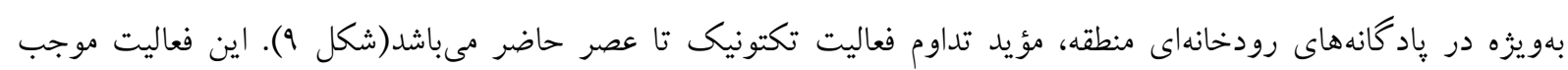

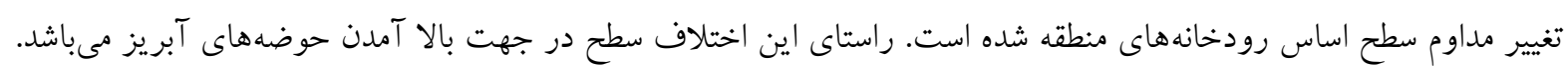
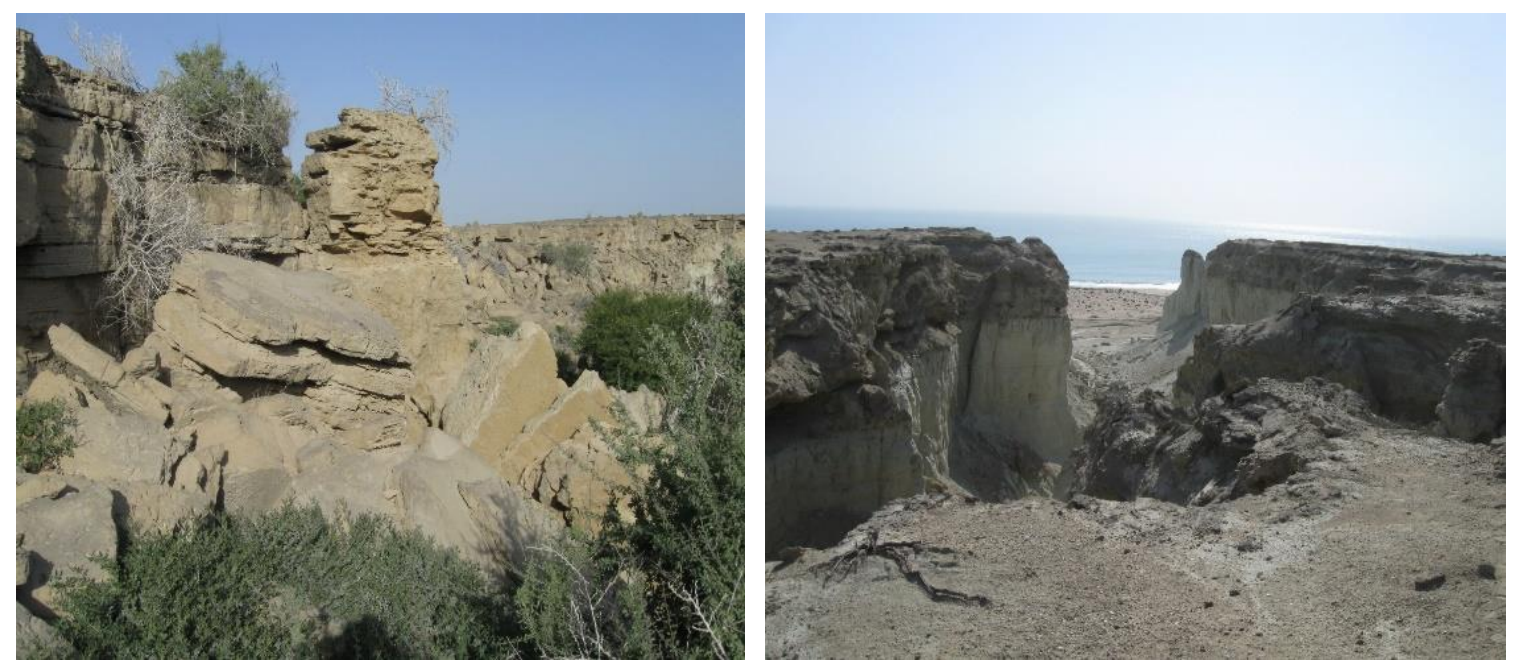

شكل q- نمونه كسلهاى جوان در باد كانههاى رودخانهاى در حوضههاى موردمطالعه

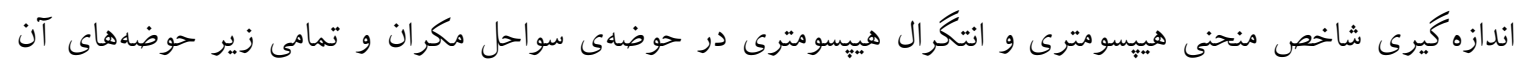

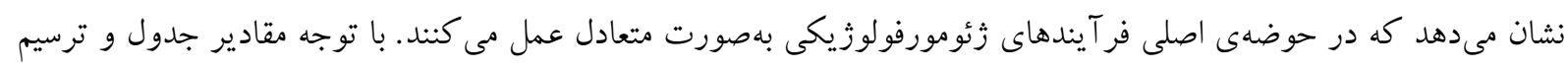

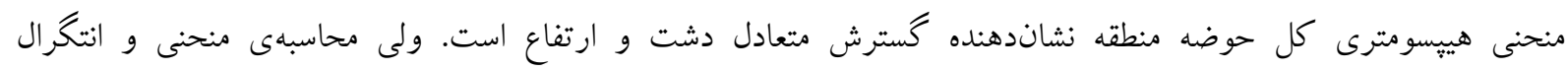

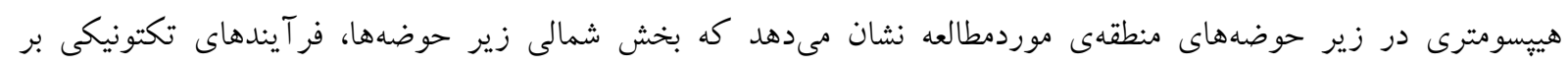

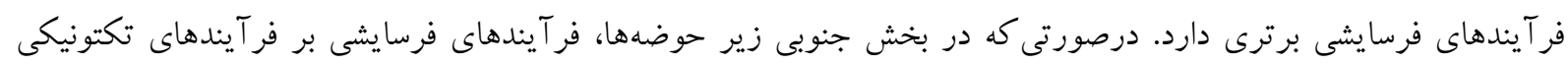

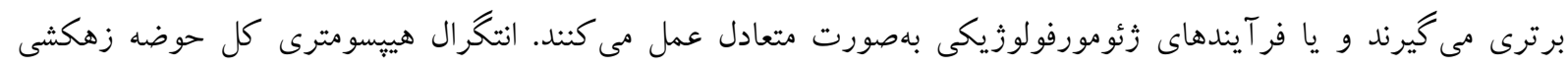
برابر ·r٪ است.

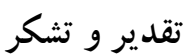

براى انجام اين يزوهش از كمك و يارى اساتيد بزرگوار و نيز مهندس سينا صلحى بهنظور تجزيهو تحليل يافتها صميمانه

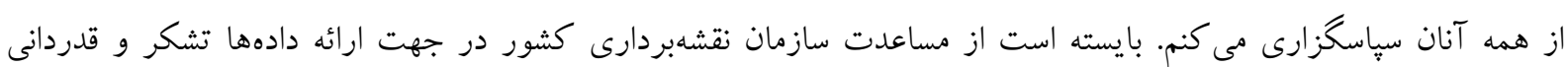

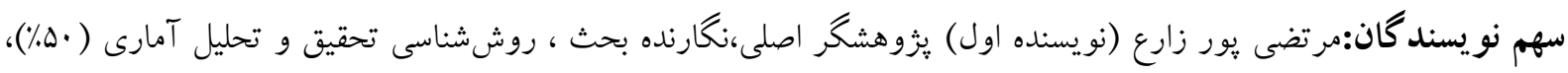

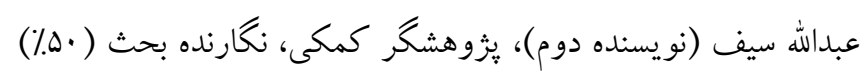



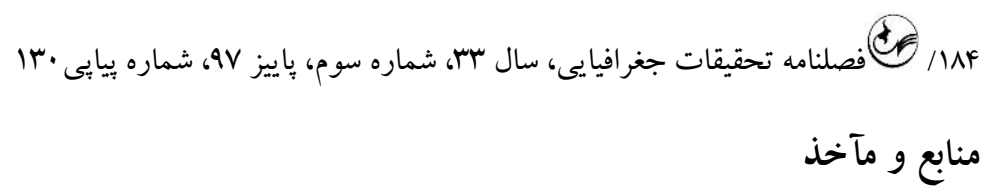

Abedini, M., \& Shabrang, S. (2014). Evaluation of neo tectonic activities in Meshkin Chai Catchment area by geomorphologic indices. Geography and Development, 12(35), 49-66. (Persian). [DOI:10.22111/GDIJ.2014.1554]

Chen, Y. C., Sung, Q., \& Cheng, K.-Y. (2003). Along-strike variations of morphotectonic features in the Western Foothills of Taiwan: tectonic implications based on stream-gradient and hypsometric analysis. Geomorphology, 56(1), 109-137. [DOI:10.1016/S0169-555X(03)00059-X]

Dehbozorgi, M., Pourkermani, M., Arian, M., Matkan, A. A., Motamedi, H., \& Hosseiniasl, A. (2010). Quantitative analysis of relative tectonic activity in the Sarvestan area, central Zagros, Iran. Geomorphology, 121(3), 329-341. [DOI:10.1016/j.geomorph.2010.05.002]

El Hamdouni, R., Irigaray, C., Fernández, T., Chacón, J., \& Keller, E. A. (2008). Assessment of relative active tectonics, southwest border of the Sierra Nevada (southern Spain). Geomorphology, 96(1), 150-173. [DOI:10.1016/j.geomorph.2007.08.004]

Ezati, M., \& Agh-Atabaei, M. (2014). An analysis of towed active construction of the Bojnourd Basin using morphotectonic indicators. Journal of Quantitative Geomorphological Researches, 2(4), 130-144. (Persian).

Giaconia, F., Booth-Rea, G., Martínez-Martínez, J. M., Azañón, J. M., Pérez-Peña, J. V., Pérez-Romero, J., \& Villegas, I. (2012). Geomorphic evidence of active tectonics in the Sierra Alhamilla (eastern Betics, SE Spain). Geomorphology, 145-146, 90-106. [DOI:10.1016/j.geomorph.2011.12.043]

Gurabi, A., \& Emami, K. (2017). Neotectonics influences on morphological variations of Makran costal basins. Journal of Quantitative Geomorphological Research, 6(1), 74-89. (Persian).

Haghipour, N., \& Burg, J. P. (2014). Geomorphological analysis of the drainage system on the growing Makran accretionary wedge. Geomorphology, 209, 111-132. [DOI:10.1016/j.geomorph.2013.11.030]

Jamieson, S. S. R., Sinclair, H. D., Kirstein, L. A., \& Purves, R. S. (2004). Tectonic forcing of longitudinal valleys in the Himalaya: morphological analysis of the Ladakh Batholith, North India. Geomorphology, 58(1), 49-65. [DOI:10.1016/S0169-555X(03)00185-5]

Keller, E. A., \& Pinter, N. (2002). Active tectonics, Earthquakes, Uplift and Landscape (Second ed.). New Jersi: Prentice Hall.

Nakhaei, M., \& Ghanavati, E. (2006). Application of hyssometric curves in determining areas under erosion and sedimentation in Kheyrabad Watershed, Kohgiluyeh and Boyer Ahmad. Iranian Geology Journal, 2(4), 65-72. (Persian)

Pedrera, A., Pérez-Peña, J. V., Galindo-Zaldívar, J., Azañón, J. M., \& Azor, A. (2009). Testing the sensitivity of geomorphic indices in areas of low-rate active folding (Eastern Betic Cordillera, Spain). Geomorphology, 105(3), 218-231. [DOI:10.1016/j.geomorph.2008.09.026]

Pourkermani, M., \& Solgi, A. (2009). Morphotectonics (First ed.). Tehran: Islamic Azad University, Research Branch. (Persian).

Rockwell, T. K., Keller, E. A., \& Johnson, D. L. (1985). Tectonic geomorphology of alluvial fans and mountain fronts near Ventura, California. Paper presented at the Tectonic Geomorphology. Proceedings of the 15 th Annual Geomorphology Symposium, Boston.

Rustaei, M., \& Agh-Atabaei, M. (2015). Quantitative analysis of the impact of neo tectonic activity the index on morphotectonic in the catchment ziyarat. Quarterly Journal of Geographical Research, 30(2), 131-146. (Persian).

Ruszkiczay-Rüdiger, Z., Fodor, L., Horváth, E., \& Telbisz, T. (2009). Discrimination of fluvial, eolian and neotectonic features in a low hilly landscape: A DEM-based morphotectonic analysis in the Central Pannonian Basin, Hungary. Geomorphology, 104(3), 203-217. [DOI:10.1016/j.geomorph.2008.08.014]

Salari, M., \& Moradi, O. (2009). Application of dimensionless hypsometric curves in evaluation of erosion and sedimentation areas in Baneh watershed. Geographical Information Quarterly (Sepehr), 18(69), 49-51. (Persian).

Singh, O. (2009). Hypsometry and erosion proneness: a case study in the lesser Himalayan Watersheds. Journal of Soil and Water conservation, 8(2), 53-59.

Strahler, A. N. (1952). Hypsometric (area-altitude) analysis of erosional topography. Bulletin of the Geological Society of America, 63(11), 1117-1142. [DOI:10.1130/0016-7606] 